\title{
History Frontiers: An Interview with Roy Rosenzweig
}

\section{John H. Summers}

Roy Rosenzweig received his Ph.D. in American history from Harvard University in 1978. Since then, he has established a reputation as one of the most innovative and talented historians of his generation. Professor Rosenzweig's dissertation, published in 1983 as Eight Hours for What We Will: Workers and Leisure in an Industrial City, 1880-1920, continues to find new readers, while more recent offerings such as his 1992 book, The Park and the People: A History of Central Park (co-authored with Elizabeth Blackmar) gather multiple awards. During much of the last decade, he has led professional historians in their attempt to find scholarly uses for cd-rom, the Internet, and other "new media." With collaborators at the American Social History Project, he wrote and produced the multimedia cd-rom Who Built America?: From the Centennial Celebration of 1876 to the Great War of 1914 (1993), which won the American Historical Association's James Harvey Robinson award for 1995 and was a finalist at the Interactive Media Festival. (A second volume, covering the interwar period, will be released later this year.) And in 1994, he founded the Center for History and New Media, which sponsors a wide array of Web-based teaching activities. Professor Rosenzweig is currently College of Arts and Sciences Distinguished Scholar in History and Director of Center for History and New Media at George Mason University, where he has taught since 1981.

JS: Professor Rosenzweig, you trained at Harvard in the 1970s. Can you reflect on that experience? From your view at George Mason University, how has history graduate training changed in the past twenty years?

RR: I' $m$ not sure that I am the best person to make this comparison because I don't teach in a department with a doctoral program. My impression is that there is today a higher degree of early professionalization - or pressure for professionalization. Graduate students seem much more likely to give papers at scholarly conferences, for example. I also think that at least for a significant group of people who started when I did (in the early 1970s), the "sixties" were still very much alive. This subgroup of early 1970s grad students had participated to some degree in the New Left and the antiwar movement, and 
those concerns still shaped their work in history. They were looking for connections between politics and history and looking for ways to "use" the past. They saw direct connections between doing "history from the bottom up" or "social history" and the politics of the 1960s.

JS: Has early professionalization helped to diminish this vital connection between politics and academic history?

RR: It seems to me that pressure for professionalization is more of an effect than a cause. The connection between politics (or activist politics) and history grew largely out of the existence of political movements. The waning of those political movements made it harder (but not impossible) to achieve those connections. The absence of political activism made professionalization more likely rather than the other way around. Of course, the other piece of this - and this was true in the 1970 s as well — is the bad job market, which fosters early professionalization. But you could argue that in earlier periods - say the $1950 \mathrm{~s}$ or early $1960 \mathrm{~s}$ - it was not that graduate schools opposed professionalization, it was just that they favoured a different road to professionalization. In that version, you apprenticed and then moved more slowly into conventional professional roles (giving papers, publishing articles, etc...). So part of the change is the result of the reorganization - and really diversification - of academic life. For example, when you get more different professional organizations and more different conferences, you get more opportunities for graduate students to give papers.

JS: With the publication of Eight Hours for What We Will, your work fell under the rubric of "labour history," but your more recent undertakings - The Park and the People, the Who Built America? cd-rom - resist easy classification. Should today's younger scholars attempt to establish themselves in a particular subdiscipline before venturing across the usual boundaries, as you seem to have done?

RR: I guess that there can be professional advantages to defining yourself within a subdiscipline. But it can also be intellectually narrowing. I think that part of the choice has to do with temperament as much as anything else. Some people, I suspect, feel more comfortable with the mastery that comes with staying within a particular area; others (like me) get more easily bored. I would say that some of the appeal of labour history at the time I started was the community. There was, at least at that moment, great energy in the field and a 
wonderfully supportive feeling among the people working in the area. Some of that, I believe, came from the fact that some of the key senior figures in the field like Herb Gutman and David Montgomery were very encouraging and helpful to younger historians.

JS: Since those early days, you have been involved with the American Social History Project - a creative group that presents history through film, cdrom, and other media - and have co-authored and co-edited a half dozen books and films. Did you set out to engage purposefully in collaborative work, or has your comfort with multiple-authorship developed over time? Do you hope to see more scholars engaging in this type of scholarship?

RR: I'm not sure that there is that much intentionality in what I have done. It is true that I have probably done more collaborative work than most historians, who tend to work in a fairly individualistic mode. I suppose that there are temperamental, practical, and "political" (in a broad sense) reasons for this. First, I like working with other people. It is often more fun that working alone. Second, some of the projects in which I have been engaged are simply too big or too complicated to be done by a single person. Third, since I think that history should be a "social" act (i.e., its significance only comes from its impact on the world), it makes sense for historians to work in more "social" ways - in collaboration with others. I have just been re-reading Carl Becker's terrific 1931 essay, "Everyman His Own Historian," and he has a great line in there saying that "the history that lies inert in unread books does no work in the world." If our goal is to "work in the world" (or as Becker puts it: "our proper function is not to repeat the past but to make use of it"), then we can probably often do this better in collaboration and conversation with others - both others who write, present, and teach history for a living and the people for whom we are ostensibly researching, teaching, and writing history.

JS: The "political" element of your answer is reminiscent of your response to Thomas Bender's 1987 call for historical synthesis. There, you suggested that professional historians should ask "who are we trying to reach and why," and "what are we trying to say to them?" In what sense do you see your work - the Who Built America? cd-rom, for instance - working "in the world," to return to Becker's phrase?

RR: I think that the key thing that drew me to working with "new media" was the possibility of reaching new and diverse audiences. The "new social 


\section{Left History 7.1}

history" and "new cultural history" have had enormous impact on scholarship, but a key other task is taking that new research into the lives of ordinary people and bringing it to classrooms and to non-academic audiences. Lots of people have taken up that challenge with films, curriculum projects, community history projects and the like. The Who Built America? cd-rom is another effort in that direction, but using a new (or now relatively new) medium.

JS: If the success of Who Built America? is a reliable indication, the notion of presenting the past through "new" media has made significant inroads since the 1990s. Are historians more receptive to unconventional formats than their reputation suggests? Taking this a little further, do you foresee a time when graduate students might publish their dissertations in new media?

RR: I'm not sure that historians are particularly different from other academics in terms of new technology and new media - a similar mix of people who are enthusiastic, hostile, and indifferent. But I would say that the emergence of e-mail and the web has moved technology/new media more into the center of things for historians and other humanists because it is now more about the content than about the technology. The largest amount that has been done by historians in new media (including by me) is in teaching applications and what we could call "public history." The area where the least has been done is in presenting scholarship in new media. To be sure, we have on-line journals and the like, but they are mostly electronic translations of the text. They don't make any particular use of the medium - beyond the great advantages in distribution. (And there are some places where people are publishing dissertations electronically - but again the goal is offering better distribution, not rethinking format.) In the next couple of years, we will start to see more experiments in which people try to exploit the possibilities of the new media (especially hypertext) to present scholarly work. It could be that some people will try this for dissertations, although for obvious reasons dissertations tend not to be the place where people most readily experiment with new forms. Doctoral dissertations are a conservative form.

JS: Both critics and supporters of new media seem to agree that hypertext erodes traditional, narrative-based modes of learning. Sven Birkerts, a noted detractor of innovations like the cd-rom, even suggests that a "new cognitive paradigm" has emerged in recent years. What, in your view, are the main differences between hypertext and narrative, and what are some of the implications of those differences? 
RR: I think that there are two different kinds of answers to that question and they go to the heart of what is or isn't different in electronic media and new media. One answer is what we could call a "quantitative" difference - the electronic book gives us more resources (5,000 pages of text or 800 pictures), it gives us different kinds of resources (film and audio as well as text and images), and it allows us to access them very quickly (we can search for anything in 10 seconds, we can quickly link things together). It is easy to substantiate this "quantitative" claim. But does the electronic medium make a "qualitative" difference - does it foster a different learning or reading or intellectual experience? Does it, for example, challenge the authority of a master narrative by breaking apart the ostensibly seamless narrative of a textbook? Does it empower a student by allowing her/him to locate primary documents that challenge the narrative provided by the text? Does the ability to move quickly among disparate bodies of material allow different kinds of learning? I'm not sure that we yet have enough evidence about the epistemological and intellectual challenges posed by new media to answer these questions. But it is something we need to be thinking about and looking at.

JS: Presumably you and your colleagues at the Center for History and New Media will be attending to such questions. What projects are underway at the Center? Will you also continue to work in more conventional formats?

RR: We have a number of projects that continue with experimenting with new media and with thinking about how these materials can be used in teaching. (A good overview of our work is on our web site at http://chnm.gmu.edu). One project, which like most of our work is a collaboration with the American Social History Project, is "Images of the French Revolution." It focuses on the visual images of the French Revolution, and will be both on the web and on cd-rom. We are collaborating with leading French historians on this, particularly Lynn Hunt of the University of Pennsylvania and Jack Censer from George Mason University. We are continuing our work with the "New Media Classroom"- a series of seminars and workshops that focus on how to use new media in the history and American studies classroom. Related to that is a web site called "History Matters." Funded by the Kellogg Foundation, it provides a gateway into web-based resources for teachers of the U.S. History survey course. "Landscapes in Time" is more of an effort to reach an out-of-school public audience with a "game-like" exploration of historical events and landscapes. Our pilot in this takes off from the story of Irish immigration and the Molly Maguires. Although much of my recent work has focused on new media, I have 


\section{Left History 7.1}

not abandoned more traditional media, which I think will live on for a long time. I have a book, recently published by Columbia University Press, that I have written with Dave Thelen, which looks at how Americans use and understand the past. It is based on a nationwide survey with a cross-section of Americans as well as additional samples of African Americans, Mexican Americans, and Oglala Sioux Indians. The title is The Presence of the Past: Popular Uses of History in American Life. I am also currently thinking about a project that combines my background as a historian with more recent interest in cyberspace - a history of the Internet.

JS: Professor Rosenzweig, thank you for your time. 